\title{
Alzheimerio ligos patogenezė ir rizikos veiksniai
}

\author{
A. Gerulytė* \\ L. Strumylaitė** \\ *Lietuvos sveikatos mokslu \\ universitetas, Medicinos akademija, \\ Medicinos fakultetas \\ **Lietuvos sveikatos mokslu \\ universitetas, Medicinos akademija, \\ Medicinos fakultetas, \\ Neuromokslu institutas
}

\begin{abstract}
Santrauka. Straipsnyje apžvelgiamos pagrindinė Alzheimerio ligos patogenezę aiškinanti hipotezė apie $\beta$ amiloido plokštelių ir neurofibrilinių rezginių formavimąsi bei kaupimąsi smegenyse ir šią hipotezę papildančios teorijos apie mikroelementų vario ir cinko apykaitos sutrikimų mechanizmus, ekscitotoksiškumą, cholinerginès sistemos disfunkciją ir autofagijos sutrikimą. Taip pat nagrinejjami mechanizmai, kuriais Alzheimerio ligos rizikos veiksniai (padidejjęs kraujo spaudimas, cukrinis diabetas, sumažėjęs fizinis aktyvumas, smegenų trauma ir kai kurių psichotropinių vaistų vartojimas) prisideda prie ligos formavimosi.
\end{abstract}

Raktažodžiai: Alzheimerio liga, demencija, patogenezè, rizikos veiksniai.

\section{IVADAS}

$2018 \mathrm{~m}$. demencija sirgo $50 \mathrm{mln}$. žmonių, iš kurių apie 60-80 \% sudarè Alzheimerio liga (AL) - dažniausia demencijos forma $[1,2]$. AL yra lètinè, degeneracinè, negrị̌žtama smegenų liga, kurios metu dẻl neuronų žūties pasireiškia atminties, kalbos ir orientacijos sutrikimai [3]. Sergamumas AL nepriklauso nuo lyties, tačiau didesnè dalis pacientų yra moterys, tikètina, dẻl ilgesnès gyvenimo trukmès. Sergamumas AL didèja su amžiumi - dvigubėja kas 5 m. nuo 65 m. amžiaus [4, 5]. Apskaičiuota, kad dèl gyventojų senėjimo $2030 \mathrm{~m}$. pasaulyje gyvens $82 \mathrm{mln}$., o 2050 m. - 152 mln. demencija sergančių žmonių [2].

AL neigiamai veikia sergančiojo gyvenimo kokybę, lemia gretutinių ligų išsivystymą ir trumpina gyvenimo trukmę [6]. 2012 m. Tinetti ir bendraautorių paskelbtame 22896 vyresnio amžiaus pacientų tyrime nustatyta, kad demencija - antra dažniausia mirties priežastis. Demencija tiesiogiai mirties nesukelia, bet lemia mirtinų gretutinių ligų, ypač infekcinių, išsivystymą [7].

Svarus Alzheimerio ligos ekonominis poveikis 2018 m. demencija sergančių pacientų priežiūrai visame pasaulyje buvo išleistas $1 \mathrm{mlrd}$. JAV dolerių. Manoma, kad nuo 2030 m. ši suma padidès 2 kartus - kasmet bus iš-

\author{
Adresas: \\ Austeja Gerulyte \\ El.paštas austeja.ger@gmail.com
}

leidžiama 2 mlrd. JAV dolerių. Du trečdaliai demencija sergančiu pacientų gyvena mažas ar vidutines pajamas gaunančiose šalyse. Manoma, kad 2050 m. šis skaičius sieks $71-72 \%$ [2].

\section{DARBO TIKSLAS}

Aptarti Alzheimerio ligos patogenezę aiškinančius mechanizmus ir pagrindinius šios ligos rizikos veiksnius.

\section{TYRIMO METODIKA}

Atlikta mokslinių straipsnių paieška elektroninėse duomenų bazėse PubMed (MEDLINE), ScienceDirect ir Wiley Online Library, naudojant raktinius žodžius „Alzheimer disease AND (pathogenesis OR risk factors)“. Atrinkta ir apibendrinta informacija pateikiama šiame straipsnyje.

\section{REZULTATAI IR JŲ APTARIMAS}

\section{Vyraujanti hipotezė}

Šiuo metu $\beta$ amiloido plokštelių ir neurofibrilinių rezginių formavimasis bei kaupimasis smegenyse yra laikomi pagrindiniais AL patogenezès mechanizmais.

(c) Neurologijos seminarai, 2019. Open Access. This article is distributed under the terms of the Creative Commons Attribution 4.0 International License CC-BY 4.0 (http://creativecommons.org/licenses/by/4.0/), which permits unrestricted use, distribution, and reproduction in any medium, provided you give appropriate credit to the original author(s) and the source, provide a link to the Creative Commons license, and indicate if changes were made. 
Sveikose smegenyse amiloido pirmtako baltymą (APB), plazminès membranos glikoproteiną, daugiausiai skaido $\alpha$ ir $\gamma$ sekretazès. Kai APB kartu su $\gamma$ sekretaze intensyviai ima skaidyti ir $\beta$ sekretaze, susidaro dideli kiekiai $\beta$ amiloido monomerų. Produkcijai viršijus šalinimą, šie monomerai ima kauptis smegenyse ir už neurono ribu jungiasi i $\beta$ amiloido oligomerus arba plokšteles. Šie junginiai trikdo nervinių impulsų perdavimą, sukelia mikroglijos moduliuojamas uždegimines reakcijas [8] ir aktyvuoja fermentą kinazę, kuris hiperfosforilina neuronų ataugų mikrotubules stabilizuojantị baltymą Tau. Hiperfosforilintas Tau baltymas nebeatlieka savo funkcijos, keičia formą ir sukimba ị intraląstelinius neurofibrilinius rezginius. Taip pažeisti neuronai negali užtikrinti medžiagų pernašos ir žūsta apoptozès būdu. Šiems patologiniams procesams užsitęsus, ryškèja smegenų atrofija ir pasireiškia klinikiniai AL simptomai [9, 10].

$\beta$ amiloido plokšteliụ svarbą patogenezèje patvirtina šeiminiai Alzheimerio ligos atvejai - juos sukeliančios genų mutacijos visada lemia padidintą $\beta$ amiloido produkciją arba sumažèjusį pašalinimą [11-13]. Be to, APB geno mutacija A673T, kuri riboja APB skaidymą $\beta$ sekretaze, mažina tikimybę sirgti AL [14].

2007-2012 m. buvo vykdytas 3-iosios fazès klinikinis tyrimas, kurio metu tirtas bapineuzumabo, monokloninio antikūno prieš $\beta$ amiloidą, veiksmingumas. Nustatyta, kad vaistas mažina amiloido kaupimąsi, bet negerina pacientų kognityvinių funkcijų [15]. 2018 m. Honing ir bendraautoriai tyrè monokloninị antikūnị solanezumabą - 3-iosios fazès klinikinio tyrimo rezultatai parodè, kad pacientams, sergantiems lengva $\mathrm{AL}$, vaistas nebuvo efektyvus [16]. 2019 m. kovo mènesị 3-iosios fazès tyrimas su monokloniniu antikūnu adukanumabu buvo nutrauktas dèl vaisto neefektyvumo, tačiau $2019 \mathrm{~m}$. spalį tyrimo duomenų analizejje buvo rasta klaida. Nauji skaičiavimai parodé, kad didelès adukanumabo dozès vis dèlto sulètino pacientų kognityvinių funkcijų blogèjimą. Šiuo metu siekiama pratęsti adukanumabo klinikinius tyrimus didelėmis dozėmis ir įsitikinti vaisto veiksmingumu [17, $18]$.

2009 m. išspausdinto klinikinio tyrimo rezultatai parodè, kad tarenflurbilas, kuris modifikuoja $\gamma$ sekretazès veikimą, nèra efektyvus pacientams, sergantiems lengva $\mathrm{AL}$ [19], o $2013 \mathrm{~m}$. Doody ir bendraautorių paskelbtame tyrime nustatyta, kad semagacestatas, $\gamma$ sekretazès inhibitorius, ne tik nepagerino pacientų kognityvinès būklès, bet ir buvo susijęs su dideliu skaičiumi nepageidaujamų reakcijų, įskaitant odos věži ir infekcijas [20].

Klinikiniai tyrimai su $\beta$ sekretazès veikimą blokuojančiais vaistais lanabecestatu ir verubecestatu taip pat buvo nutraukti dèl neefektyvumo [21].

Didelis nesėkmių skaičius, ieškant vaistų, mažinančių $\beta$ amiloido kieki arba darančiu poveikị $\gamma$ ar $\beta$ sekretazėms $[22,23]$, skatina ieškoti alternatyvių AL patogenezę aiškinančių hipotezių, kurios pakeistų arba papildytų pagrindinę hipotezę ir padètų sukurti efektyvų etiologinį AL gydymą.

\section{Alternatyvios hipotezès}

Mikroelementų, ypač vario ir cinko, apykaitos sutrikimai stebimi pacientų, sergančių AL, smegenyse [24].

Sergančiujjų nerviniame audinyje randama sumažějusi, o smegenų skystyje - padidejusi vario (bendra vario ir vario, nesusijungusio su ceruloplazminu) koncentracija [25, 26]. Varis geba prisijungti prie $\beta$ amiloido ir Tau baltymo, taip pagreitindamas jų agregaciją, ir tiesiogiai skatina oksidacinị stresą bei laisvųjų radikalų, pažeidžiančių nervinị audinį, formavimąsi [27-29]. Be to, neuronų postsinapsinèse membranose varis blokuoja $\mathrm{N}$-metil-D-aspartato (NMDA) ir $\alpha$-amino-3-hidroksi-5-metil-4-isoksasolepropioninès rūgšties receptorius, todèl itin sumažèja glutamato stimuliuojantysis poveikis, lemiantis kongnityviniu funkcijų blogèjimą [30].

Cinkas dalyvauja APB metabolizme ir didina $\beta$ amiloido produkciją [31, 32]. Taip pat tiesiogiai jungiasi prie Tau baltymo, inhibuoja fosfatazę $2 \mathrm{~A}$ ir aktyvuoja Tau fosforilinančią kinazę bei skatina hiperfosforilinto Tau agregaciją [33]. Cinkas, kitaip nei varis, nèra redukuojantis metalas, todèl oksidacinį stresą gali sukelti tik netiesiogiai, aktyvuodamas reaktyvius deguonies ir azoto junginius gaminančius fermentus 12-lipoksigenazę, redukuoto nikotinamido adenino dinukleotido fosfato oksidazę ir azoto monoksido sintazę. Susidarę deguonies ir azoto oksido radikalai jungiasi tarpusavyje ir suformuoja stiprų neurotoksinị poveikị turintį peroksinitritą. Iš oksidacinio streso pažeistų ląstelių išsiskiria dar daugiau cinko ir susidaro uždaras patogenezinis ratas [34].

Ekscitotoksiškumas, patologinis procesas, kurio metu pažeidžiami neuronai dèl labai intensyvaus stimuliavimo neurotransmiteriais, yra svarbus Alzheimerio ligos patogenezèje [10]. Manoma, kad $\beta$ amiloidas gali stimuliuoti $\alpha 7$-nikotininius receptorius presinapsinèse neuronu membranose, didinti glutamato išskyrimą ị sinapsę, pažeisti stimuliuojančių amino rūgščių transporterị astrocituose ir sutrikdyti glutamato pašalinimą iš sinapsès [35]. Glutamatas aktyvuoja NMDA receptorius postsinapsineje membranoje ir sukelia $\mathrm{Ca}^{2+}$ patekimą į neuroną [36]. Didelè $\mathrm{Ca}^{2+}$ koncentracija ląstelèje aktyvuoja apoptozès mechanizmus ir ilgainiui sukelia ryškią smegenų atrofiją [37]. Šią hipotezę patvirtina memantino, NMDA receptorius blokuojančio vaisto, veiksmingumas stabdant AL progresavimą [38].

Cholinerginės sistemos pažeidimai smegenų žievẻje ir hipokampe (sumažèjęs acetilcholino išskyrimas ị sinapsę, sutrikęs cholino transportas, sumažèjusi nikotininių ir muskarininių receptorių ekspresija, sutrikęs aksoninis transportas) galimai sukelia kognityvinių funkciju - kalbos, atminties ir orientacijos, sutrikimus [39]. Manoma, kad cholinerginiai pokyčiai yra neurodegeneracinio proceso pasekmé, o ne priežastis ir dažniausiai atsiranda vèlyvose jo stadijose [10]. Cholinesterazès, fermento, kuris sinapsinejje membranoje skaido acetilcholiną, inhibitoriai lengvina AL sergančių pacientų simptomus [40].

Autofagija yra pažeistų ląstelès organelių, baltymų ar kitų medžiagų degradacija lizosomose. Lizosomoms susi- 
liejus su skaidomomis struktūromis, susidaro autofagosomos, kurių itin didelis kiekis randamas AL sergančių pacientų degeneravusiuose neuronuose. Autofagosomų kaupimasis gali sukelti padidejusią $\beta$ amiloido produkciją, nes veikia APB metabolizmą [41].

2019 m. balandžio mėnesi Nelson ir bendraautoriai detaliai aprašè neseniai atrastą ligą - limbinejje sistemoje vyraujančią, su amžiumi susijusią TDP-43 encefalopatiją (angl. limbic-predominant age-related TDP-43 encephalopathy, LATE). Ši liga būdinga senyviems pacientams autopsijų metu apie $20 \%$ vyresnių nei $80 \mathrm{~m}$. pacientų smegenyse rasta LATE būdingų pakitimų (TDP-43 baltymo kaupimasis amigdaloje, hipokampe ir viduriniame kaktiniame vingyje su (be) hipokampo skleroze). Šie pakitimai smegenyse gali būti aptinkami kartu su AL būdingais požymiais arba atskirai. Be to, klinikinis LATE pasireiškimas yra labai panašus ị AL. Dèl šių priežasčių tikètina, kad kai kuriuose klinikiniuose AL vaistų tyrimuose įsimaišydavo pacientų su LATE ir taip būdavo gaunami klaidingi rezultatai. Reikalingi tolimesni tyrimai, siekiant geriau suprasti LATE epidemiologiją, patogenezę, rizikos veiksnius, rasti ligos žymenis, sukurti veiksmingą etiologinị gydymą ir užtikrinti AL vaistų tyrimų patikimumą [42, 43].

Kadangi šiuo metu nėra efektyvaus etiologinio AL gydymo, svarbu identifikuoti šios ligos rizikos veiksnius ir jų vengti.

\section{Rizikos veiksniai}

Hipertenzija, ypač netinkamai gydoma, yra svarbus AL rizikos veiksnys vidutiniame amžiuje [44]. Ji pažeidžia smegenų kraujagyslių sienelę ir kraujo-smegenų barjerą, sukelia baltymų ekstravazaciją, trikdo $\beta$ amiloido pašalinimą iš smegenų [45]. 2017 m. Gilsanz ir bendraautorių paskelbtame tyrime teigiama, kad hipertenzija $65 \%$ didina riziką sirgti AL, tačiau tik moterims [46]. Kiti tyrimai skirtumų tarp lyčių neaptiko [47-50]. Vyresniame amžiuje kraujo spaudimo ir demencijos ryšys tampa priešingas - mažesnis kraujos spaudimas koreliuoja su demencijos pasireiškimu, tačiau nèra jos priežastis [51].

Cukrinis diabetas 39-65 \% didina AL pasireiškimo tikimybę [45, 47]. Dèl insulino konkuravimo su $\beta$ amiloidu dèl insuliną skaidančių fermentų mažejja $\beta$ amiloido klirensas. Tuo tarpu smegenyse susidariusios ar susikaupusios glikuotos medžiagos didina $\beta$ amiloido agregaciją - formuojasi toksiški $\beta$ amiloido oligomerai ir plokštelès [45]. Tinkama glikemijos korekcija vaistais ir dieta gali mažinti lengvos demencijos ar AL simptomus [52, 53].

Dislipidemija, ypač padidejęs bendras cholesterolio arba mažo tankio lipoproteinų (MTL) kiekis, vidutinio amžiaus pacientams 3 kartus didina riziką susirgti AL senatvejje [47]. Padidejjęs cholesterolio ir MTL kiekis skatina $\beta$ amiloido susidarymą ir kaupimąsi smegenyse, tačiau tikslūs mechanizmai nėra iki galo aiškūs. MTL iš periferinès kraujotakos nepatenka į smegenis, nebent būtų pažeistas kraujo-smegenų barjeras. Beveik visą cholesterolị smegenyse gamina astrocitai, neuronai arba atneša didelio tankio lipoproteinai [54]. Tikètina, kad dislipidemija prie AL vystymosi prisideda netiesiogiai - skatina aterosklerozės, širdies ir kraujagyslių bei smegenų kraujotakos ligų vystymąsi [55].

Antsvoris (kūno masės indekso (KMI) - 25-30 kg/m²) ir nutukimas (KMI $\left.>30 \mathrm{~kg} / \mathrm{m}^{2}\right)$ vidutiniame amžiuje apie $50 \%$ didina riziką sirgti AL senatvejje. Šis ryšys tikriausiai taip pat yra netiesioginis - antsvoris ir nutukimas skatina širdies ir kraujagyslių ligų vystymąsi [56]. Tam tikruose tyrimuose taip pat buvo nustatyta sąsaja tarp mažo KMI $\left(<18,5 \mathrm{~kg} / \mathrm{m}^{2}\right)$ ar kūno svorio kritimo senyvame amžiuje ir demencijos ar AL pasireiškimo. Kūno masès mažèjimą prieš demencijos pasireiškimą gali sukelti daug faktorių sumažèjęs suvalgomo maisto kiekis, mažèjantis judrumas, pati demencija ar gretutinès ligos [57].

Širdies ir kraujagyslių bei smegenų kraujotakos ligos yra rizikos veiksniai ne tik Alzheimerio ligai, bet ir kraujagyslinei demencijai [47]. 34-50\% pacientų, sergančių AL, smegenyse randama ir kraujagyslių patologijos (Viliso rato arterijų aterosklerozè, periventrikulinès baltosios medžiagos pažeidimai, žievės infarktai). Trečdaliui pacientų, sergančių kraujagysline demencija, autopsijose randama AL būdingų pokyčių $[58,59]$. Širdies ir kraujagyslių bei smegenų kraujotakos ligos pažeidžia kraujagyslių sienelę bei kraujo-smegenų barjerą ir taip trikdo $\beta$ amiloido pašalinimą iš smegenų [60]. Tam tikruose tyrimuose nustatyta, kad smegenų kraujotakos pokyčiai atsiranda pirmiau nei AL pokyčiai, todėl manoma, kad kraujagyslių patologija gali būti pirminis AL etiologinis faktorius [61].

2017 m. atlikta sisteminė apžvalga nustatė, kad fizinis neaktyvumas didina riziką susirgti AL, o fizinè veikla, ypač sporto rūšys, kuriose yra papildomų socialinių komponentų, pvz., komandinis sportas, riziką mažina [62] $2016 \mathrm{~m}$. Santos-Lozano ir bendraautoriuc paskelbtoje metaanalizèje teigiama, kad vyresnio amžiaus (70-80 m.) pacientai, kurie paskutinius 5 ar daugiau metų buvo fiziškai aktyvūs, t. y. užsièmé $\geq 150 \mathrm{~min}$. vidutinio intensyvumo arba $\geq 75$ min. didelio intensyvumo fizine veikla per savaitę, turèjo 40 \% mažesnę riziką susirgti AL nei jų fiziškai neaktyvūs bendraamžiai [63]. Aktyvi fizinè veikla gerina smegenų kraujotaką ir taip didina $\beta$ amiloido pašalinimą. Taip pat skatinamas smegenų neurotropinio faktoriaus išsiskyrimas (angl. brain-derived neurotrophic factor), kuris mažina $\beta$ amiloido produkciją ir neurotoksiškumą, didina neuronų išgyvenamumą, sinapsių formavimąsi ir smegenų plastiškumą [64]. Pastebèta, kad fizinis aktyvumas stabdo hipokampo, atsakingo už mokymąsi ir atmintị, atrofiją. Be to, aktyvi fizinè veikla mažina beveik visų kitų Alzheimerio ligos rizikos veiksnių (hipertenzijos, cukrinio diabeto, dislipidemijos, viršsvorio ir nutukimo, kardiovaskulinių ir cerebrovaskulinių ligų) pasireiškimo tikimybę [65].

$2014 \mathrm{~m}$. Hong ir bendraautoriai ištyrè, kad dèl galvos smegenų traumos smegenų žievèje ir dryžuotajame kūne dideja $\beta$ amiloido sankaupos [66]. Vidutinio sunkumo galvos smegenų trauma didina riziką susirgti AL 2 kartus, sunki - 4 kartus [47].

Manoma, kad kai kurie vaistai gali didinti riziką sirgti AL. 2014 m. Gage ir bendraautorių atlikto tyrimo duomenimis, benzodiazepinai didina riziką sirgti AL 1,5 karto 
[67]. Taip pat jie skatina ligos progresavimą, jeigu yra skiriami jau AL sergantiems pacientams [68]. 2010 m. eksperimentinis tyrimas su pelèmis patvirtino, kad diazepamas skatina $\beta$ amiloido kaupimąsi smegenyse [69], tačiau detalesni patogeneziniai mechanizmai lieka neaiškūs. Nustatyta, kad, kaip ir benzodiazepinai, anticholinergini poveiki turintys vaistai (pvz., tricikliai antidepresantai, pirmos kartos antihistamininiai, varfarinas ir pan.) 1,5 karto didina riziką sirgti AL. Šie vaistai trikdo smegenų cholinerginès sistemos veiklą, taip lemdami kognityvinių funkcijų sutrikimus [70].

\section{APIBENDRINIMAS}

Pagrindines Alzheimerio ligos patogenezès teorijas apie $\beta$ amiloido plokštelių ir neurofibrilinių rezginių formavimąsi bei kaupimąsi smegenyse papildo mikroelementų vario ir cinko apykaitos sutrikimas, ekscitotoksiškumas, cholinerginès sistemos disfunkcija ir autofagijos sutrikimas. Iki galo nesuprasta AL patogenezè trukdo kurti etiologini gydymą. Nesant efektyvaus gydymo, rekomenduojama identifikuoti AL rizikos veiksnius ir jų vengti.

\section{Literatūra}

1. Alzheimer's Association. 2019 Alzheimer's disease facts and figures. Alzheimer's Dement 2019; 15: 321-87. https://doi.org/10.1016/j.jalz.2019.01.010

2. Alzheimer's Disease International. World Alzheimer Report 2018. The state of the art of dementia research: new frontiers.

3. Knopman DS, Petersen RC, Jack CR. A brief history of "Alzheimer disease": multiple meanings separated by a common name. Neurology 2019; 92(22): 1053-9. https://doi.org/ 10.1212/WNL.0000000000007583

4. Lane CA, Hardy J, Schott JM. Alzheimer's disease. Eur J Neurol 2018; 25: 59-70. https://doi.org/10.1111/ene.13439

5. Prince M, Bryce R, Albanese E, Wimo A, Ribeiro W, Ferri CP. The global prevalence of dementia: a systematic review and metaanalysis. Alzheimers Dement 2013; 9: 63-75.e2. https://doi.org/10.1016/j.jalz.2012.11.007

6. Schumann C, Alexopoulos P, Perneczky R. Determinants of self and carer rated quality of life and caregiver burden in Alzheimer's disease. Int J Geriatr Psychiatry 2019; 34: 1378-85. https://doi.org/10.1002/gps.5126

7. Tinetti ME, McAvay GJ, Murphy TE, Gross CP, Lin H, Allore HG. Contribution of individual diseases to death in older adults with multiple diseases. J Am Geriatr Soc 2012; 60: 1448-56. https://doi.org/10.1111/j.1532-5415. 2012.04077.x

8. Morkuniene R, Zvirbliene A, Dalgediene I, Cizas P, Jankeviciute $S$, Baliutyte $G$, et al. Antibodies bound to A $\beta$ oligomers potentiate the neurotoxicity of $A \beta$ by activating microglia. J Neurochem 2013; 126: 604-15. https://doi.org/10.1111/ jnc. 12332

9. Kocahan S, Doğan Z. Mechanisms of Alzheimer's disease pathogenesis and prevention: the brain, neural pathology, $\mathrm{N}$-methyl-D-aspartate receptors, Tau protein and other risk factors. Clin Psychopharmacol Neurosci 2017; 15(1): 1-8. https://doi.org/10.9758/cpn.2017.15.1.1
10. Briggs R, Kennelly SP, O'Neill D. Drug treatments in Alzheimer's disease. Clin Med (Northfield Il) 2016; 16: 247-53. https://doi.org/10.7861/clinmedicine.16-3-247

11. Karch CM, Cruchaga C, Goate AM. Alzheimer's disease genetics: from the bench to the clinic. Neuron 2014; 83: 11-26. https://doi.org/10.1016/j.neuron.2014.05.041

12. Dorszewska J, Prendecki M, Oczkowska A, Dezor M, Kozubski W. Molecular basis of familial and sporadic Alzheimer's disease. Curr Alzheimer Res 2016; 13: 952-63. https://doi.org/10.2174/1567205013666160314150501

13. Cacace R, Sleegers K, Van Broeckhoven C. Molecular genetics of early-onset Alzheimer's disease revisited. Alzheimer's Dement 2016; 12: 733-48. https://doi.org/10.1016/ j.jalz.2016.01.012

14. Jonsson T, Atwal JK, Steinberg S, Snaedal J, Jonsson PV, Bjornsson S, et al. A mutation in APP protects against Alzheimer's disease and age-related cognitive decline. Nature 2012; 488: 96-9. https://doi.org/10.1038/nature11283

15. Salloway S, Sperling R, Fox NC, Blennow K, Klunk W, Raskind M, et al. Two phase 3 trials of bapineuzumab in mild-to-moderate Alzheimer's disease. N Engl J Med 2014; 370: 322-33. https://doi.org/10.1056/NEJMoa1304839

16. Honig LS, Vellas B, Woodward M, Boada M, Bullock R, Borrie M, et al. Trial of solanezumab for mild dementia due to Alzheimer's disease. N Engl J Med 2018; 378: 321-30. https://doi.org/10.1056/NEJMoa1705971

17. Schneider L. A resurrection of aducanumab for Alzheimer's disease. Lancet Neurol 2020; 19(2): 111-2. https://doi.org/ 10.1016/S1474-4422(19)30480-6

18. Sevigny $\mathrm{J}$, Chiao $\mathrm{P}$, Bussière $\mathrm{T}$, Weinreb $\mathrm{PH}$, Williams L, Maier $M$, et al. The antibody aducanumab reduces $A \beta$ plaques in Alzheimer's disease. Nature 2016; 537: 50-6. https://doi.org/10.1038/nature19323

19. Green RC, Schneider LS, Amato DA, Beelen AP, Wilcock G, Swabb EA, et al. Effect of tarenflurbil on cognitive decline and activities of daily living in patients with mild Alzheimer disease: a randomized controlled trial. JAMA 2009; 302: 2557. https://doi.org/10.1001/jama.2009.1866

20. Doody RS, Raman R, Farlow M, Iwatsubo T, Vellas B, Joffe S, et al. A phase 3 trial of semagacestat for treatment of Alzheimer's disease. N Engl J Med 2013; 369: 341-50. https://doi.org/10.1056/NEJMoa1210951

21. Egan MF, Kost J, Tariot PN, Aisen PS, Cummings JL, Vellas B, et al. Randomized trial of verubecestat for mild-to-moderate Alzheimer's disease. N Engl J Med 2018; 378: 1691-703. https://doi.org/10.1056/NEJMoa1706441

22. Mehta D, Jackson R, Paul G, Shi J, Sabbagh M. Why do trials for Alzheimer's disease drugs keep failing? A discontinued drug perspective for 2010-2015. Expert Opin Investig Drugs 2017; 26: 735-9. https://doi.org/10.1080/13543784. 2017.1323868

23. Wong KH, Riaz MK, Xie Y, Zhang X, Liu Q, Chen H, et al. Review of current strategies for delivering Alzheimer's disease drugs across the blood-brain barrier. Int J Mol Sci 2019; 20: 381. https://doi.org/10.3390/ijms20020381

24. Wang P, Wang Z-Y. Metal ions influx is a double edged sword for the pathogenesis of Alzheimer's disease. Ageing Res Rev 2017; 35: 265-90. https://doi.org/10.1016/ j.arr.2016.10.003

25. Linder MC. Ceruloplasmin and other copper binding components of blood plasma and their functions: an update. Metallomics 2016; 8: 887-905. https://doi.org/10.1039/ C6MT00103C 
26. Squitti R, Siotto M, Arciello M, Rossi L. Non-ceruloplasmin bound copper and ATP7B gene variants in Alzheimer's disease. Metallomics 2016; 8: 863-73. https://doi.org/10.1039/ C6MT00101G

27. Ayton S, Lei P, Bush AI. Metallostasis in Alzheimer's disease. Free Radic Biol Med 2013; 62: 76-89. https://doi.org/ 10.1016/j.freeradbiomed.2012.10.558

28. Tõugu V, Tiiman A, Palumaa P. Interactions of $\mathrm{Zn}$ (ii) and $\mathrm{Cu}$ (ii) ions with Alzheimer's amyloid-beta peptide. Metal ion binding, contribution to fibrillization and toxicity. Metallomics 2011; 3: 250. https://doi.org/10.1039/ $\mathrm{c} 0 \mathrm{mt} 00073 \mathrm{f}$

29. Kitazawa M, Cheng D, LaFerla FM. Chronic copper exposure exacerbates both amyloid and tau pathology and selectively dysregulates cdk5 in a mouse model of AD. J Neurochem 2009; 108: 1550-60. https://doi.org/10.1111/ j.1471-4159.2009.05901.x

30. Dodani SC, Firl A, Chan J, Nam CI, Aron AT, Onak CS, et al Copper is an endogenous modulator of neural circuit spontaneous activity. Proc Natl Acad Sci 2014; 111: 16280-5. https://doi.org/10.1073/pnas.1409796111

31. Hoke DE, Tan J-L, Ilaya NT, Culvenor JG, Smith SJ, White AR, et al. In vitro gamma-secretase cleavage of the Alzheimer's amyloid precursor protein correlates to a subset of presenilin complexes and is inhibited by zinc. FEBS J 2005; 272: 5544-57. https://doi.org/10.1111/ j.1742-4658.2005.04950.x

32. Roberts BR, Ryan TM, Bush AI, Masters CL, Duce JA. The role of metallobiology and amyloid- $\beta$ peptides in Alzheimer's disease. J Neurochem 2012; 120: 149-66. https://doi.org/10.1111/j.1471-4159.2011.07500.x

33. Sensi SL, Granzotto A, Siotto M, Squitti R. Copper and zinc dysregulation in Alzheimer's disease. Trends Pharmacol Sci 2018; 39: 1049-63. https://doi.org/10.1016/j.tips. 2018.10.001

34. Sensi SL, Paoletti P, Bush AI, Sekler I. Zinc in the physiology and pathology of the CNS. Nat Rev Neurosci 2009; 10: 780-91. https://doi.org/10.1038/nrn2734

35. Esposito Z, Belli L, Toniolo S, Sancesario G, Bianconi C, Martorana A. Amyloid $\beta$, glutamate, excitotoxicity in Alzheimer's disease: are we on the right track? CNS Neurosci Ther 2013; 19: 549-55. https://doi.org/10.1111/cns. 12095

36. Hynd M, Scott HL, Dodd PR. Glutamate-mediated excitotoxicity and neurodegeneration in Alzheimer's disease. Neurochem Int 2004; 45: 583-95. https://doi.org/10.1016/ j.neuint.2004.03.007

37. Wang R, Reddy PH. Role of glutamate and NMDA receptors in Alzheimer's disease. J Alzheimers Dis 2017; 57: 1041-8. https://doi.org/10.3233/JAD-160763

38. Kishi T, Matsunaga S, Oya K, Nomura I, Ikuta T, Iwata N. Memantine for Alzheimer's disease: an updated systematic review and meta-analysis. J Alzheimers Dis 2017; 60: 401-25. https://doi.org/10.3233/JAD-170424

39. Grossberg S. Acetylcholine neuromodulation in normal and abnormal learning and memory: vigilance control in waking, sleep, autism, amnesia and Alzheimer's disease. Front Neural Circuits 2017; 11: 82. https://doi.org/10.3389/fncir. 2017.00082

40. Risacher SL, McDonald BC, Tallman EF, West JD, Farlow MR, Unverzagt FW, et al. Association between anticholinergic medication use and cognition, brain metabolism, and brain atrophy in cognitively normal older adults. JAMA Neurol 2016; 73: 721-32. https://doi.org/10.1001/ jamaneurol.2016.0580
41. Bostanciklioğlu M. An update on the interactions between Alzheimer's disease, autophagy and inflammation. Gene 2019; 705: 157-66. https://doi.org/10.1016/j.gene. 2019.04.040

42. Besser LM, Teylan MA, Nelson PT. Limbic predominant age-related TDP-43 encephalopathy (LATE): clinical and neuropathological associations. J Neuropathol Exp Neurol 2019; 142: 1503-27. https://doi.org/10.1093/jnen/nlz126

43. Nelson PT, Dickson DW, Trojanowski JQ, Jack CR, Boyle PA, Arfanakis K, et al. Limbic-predominant age-related TDP-43 encephalopathy (LATE): consensus working group report. Brain 2019; 142: 1503-27. https://doi.org/ 10.1093/brain/awz099

44. Imtiaz B, Tolppanen A-M, Kivipelto M, Soininen H. Future directions in Alzheimer's disease from risk factors to prevention. Biochem Pharmacol 2014; 88: 661-70. https://doi.org/ 10.1016/j.bcp.2014.01.003

45. Hickman RA, Faustin A, Wisniewski T. Alzheimer disease and its growing epidemic: risk factors, biomarkers, and the urgent need for therapeutics. Neurol Clin 2016; 34: 941-53. https://doi.org/10.1016/j.ncl.2016.06.009

46. Gilsanz P, Mayeda ER, Glymour MM, Quesenberry CP, Mungas DM, DeCarli C, et al. Female sex, early-onset hypertension, and risk of dementia. Neurology 2017; 89: 1886-93 https://doi.org/10.1212/WNL.0000000000004602

47. Hersi M, Irvine B, Gupta P, Gomes J, Birkett N, Krewski D. Risk factors associated with the onset and progression of Alzheimer's disease: a systematic review of the evidence. Neurotoxicology 2017; 61: 143-87. https://doi.org/10.1016/ j.neuro.2017.03.006

48. Gottesman RF, Albert MS, Alonso A, Coker LH, Coresh J, Davis SM, et al. Associations between midlife vascular risk factors and 25-year incident dementia in the Atherosclerosis Risk in Communities (ARIC) cohort. JAMA Neurol 2017; 74: 246-54. https://doi.org/10.1001/jamaneurol.2017.1658

49. Beason-Held LL, Thambisetty M, Deib G, Sojkova J, Landman BA, Zonderman AB, et al. Baseline cardiovascular risk predicts subsequent changes in resting brain function. Stroke 2012; 43: 1542-7. https://doi.org/10.1161/ STROKEAHA.111.638437

50. Debette S, Seshadri S, Beiser A, Au R, Himali JJ, Palumbo C, et al. Midlife vascular risk factor exposure accelerates structural brain aging and cognitive decline. Neurology 2011; 77: 461-8. https://doi.org/10.1212/WNL.0b013e318227b227

51. De Bruijn RFAG, Ikram MA. Cardiovascular risk factors and future risk of Alzheimer's disease. BMC Med 2014; 12: 130. https://doi.org/10.1186/s12916-014-0130-5

52. Bayer-Carter JL, Green PS, Montine TJ, VanFossen B, Baker LD, Watson GS, et al. Diet intervention and cerebrospinal fluid biomarkers in amnestic mild cognitive impairment. Arch Neurol 2011; 68: 743-52. https://doi.org/ 10.1001/archneurol.2011.125

53. Craft S, Baker LD, Montine TJ, Minoshima S, Watson GS, Claxton A, et al. Intranasal insulin therapy for Alzheimer disease and amnestic mild cognitive impairment: a pilot clinical trial. Arch Neurol 2012; 69: 29-38. https://doi.org/10.1001/ archneurol.2011.233

54. Beel AJ, Sakakura M, Barrett PJ, Sanders CR. Direct binding of cholesterol to the amyloid precursor protein: an important interaction in lipid-Alzheimer's disease relationships? Biochim Biophys Acta - Mol Cell Biol Lipids 2010 1801: 975-82. https://doi.org/10.1016/j.bbalip.2010.03.008

55. Povova J, Ambroz P, Bar M, Pavukova V, Sery O, Tomaskova $\mathrm{H}$, et al. Epidemiological of and risk factors for 
Alzheimer's disease: a review. Biomed Pap 2012; 156: 108-14. https://doi.org/10.5507/bp.2012.055

56. Profenno LA, Porsteinsson AP, Faraone SV. Meta-analysis of Alzheimer's disease risk with obesity, diabetes, and related disorders. Biol Psychiatry 2010; 67: 505-12. https://doi.org/10.1016/j.biopsych.2009.02.013

57. Gustafson D, Rothenberg E, Blennow K, Steen B, Skoog I. An 18-year follow-up of overweight and risk of Alzheimer disease. Arch Intern Med 2003; 163: 1524. https://doi.org/ 10.1001/archinte.163.13.1524

58. Debette S, Beiser A, DeCarli C, Au R, Himali JJ, KellyHayes M, et al. Association of MRI markers of vascular brain injury with incident stroke, mild cognitive impairment, dementia, and mortality: the Framingham Offspring Study. Stroke 2010; 41: 600-6. https://doi.org/10.1161/ STROKEAHA.109.570044

59. Kalaria RN. Cerebrovascular disease and mechanisms of cognitive impairment. Stroke 2012; 43: 2526-34. https://doi.org/10.1161/STROKEAHA.112.655803

60. Crous-Bou M, Minguillón C, Gramunt N, Molinuevo JL. Alzheimer's disease prevention: from risk factors to early intervention. Alzheimers Res Ther 2017; 9: 71. https://doi.org/ 10.1186/s13195-017-0297-z

61. De la Torre JC. Alzheimer disease as a vascular disorder: nosological evidence. Stroke 2002; 33: 1152-62. https://doi.org/10.1161/01.STR.0000014421.15948.67

62. Stephen R, Hongisto K, Solomon A, Lönnroos E. Physical activity and Alzheimer's disease: a systematic review. J Gerontol Ser A 2017; 72(6): 733-9. https://doi.org/ 10.1093/gerona/glw251

63. Santos-Lozano A, Pareja-Galeano H, Sanchis-Gomar F, Quindós-Rubial M, Fiuza-Luces C, Cristi-Montero C, et al. Physical activity and Alzheimer disease: a protective association. Mayo Clin Proc 2016; 91: 999-1020. https://doi.org/ 10.1016/j.mayocp.2016.04.024

64. Song J-H, Yu J-T, Tan L. Brain-derived neurotrophic factor in Alzheimer's disease: risk, mechanisms, and therapy. Mol Neurobiol 2015; 52: 1477-93. https://doi.org/10.1007/ s12035-014-8958-4

65. Cass SP. Alzheimer's disease and exercise. Curr Sports Med Rep 2017; 16: 19-22. https://doi.org/10.1249/ JSR.0000000000000332

66. Hong YT, Veenith T, Dewar D, Outtrim JG, Mani V, Williams C, et al. Amyloid imaging with carbon 11-labeled Pitts- burgh compound B for traumatic brain injury. JAMA Neurol 2014; 71: 23-31. https://doi.org/10.1001/jamaneurol. 2013.4847

67. Billioti de Gage S, Moride Y, Ducruet T, Kurth T, Verdoux $\mathrm{H}$, Tournier M, et al. Benzodiazepine use and risk of Alzheimer's disease: case-control study. BMJ 2014; 349: g5205. https://doi.org/10.1136/bmj.g5205

68. Defrancesco M, Marksteiner J, Fleischhacker WW, Blasko I. Use of benzodiazepines in Alzheimer's disease: a systematic review of literature. Int J Neuropsychopharmacol 2015; 18: pyv055. https://doi.org/10.1093/ijnp/pyv055

69. Tampellini D, Capetillo-Zarate E, Dumont M, Huang Z, Yu F, Lin MT, et al. Effects of synaptic modulation on beta-amyloid, synaptophysin, and memory performance in Alzheimer's disease transgenic mice. J Neurosci 2010; 30: 14299-304. https://doi.org/10.1523/JNEUROSCI. $3383-10.2010$

70. Gray SL, Anderson ML, Dublin S, Hanlon JT, Hubbard R, Walker R, et al. Cumulative use of strong anticholinergics and incident dementia: a prospective cohort study. JAMA Intern Med 2015; 175: 401-7. https://doi.org/10.1001/ jamainternmed.2014.7663

\section{A. Gerulytė, L. Strumylaitė}

\section{ALZHEIMER'S DISEASE PATHOGENESIS AND RISK FACTORS}

\section{Summary}

The article reviews the main hypothesis explaining the pathogenesis of Alzheimer's disease in the formation and accumulation of $\beta$-amyloid plaques and neurofibrillary plexus in the brain as well as related theories on the mechanisms of copper and zinc dysregulation, excitotoxicity, cholinergic system dysfunction, and autophagy disorders. The main risk factors for Alzheimer's disease (increased blood pressure, diabetes, reduced physical activity, brain trauma and the influence of some psychotropic medications) are also discussed.

Keywords: Alzheimer's disease, dementia, pathogenesis, risk factors.

Gauta:

20200120

Priimta spaudai: 20200205 